\title{
Growth Performance and Radiation Use Efficiency of Transplanted Rice under Varied Plant Densities and Nitrogen Levels
}

\author{
R. Swarna, P. Leela Rani*, G. Sreenivas, D. Raji Reddy and A. Madhavi \\ Department of Agronomy, College of Agriculture, Professor Jayashankar Telangana state \\ Agricultural University, Rajendranagar, Hyderabad - 500 030, India \\ *Corresponding author
}

\section{A B S T R A C T}

\begin{tabular}{|l|}
\hline Ke y w o r d s \\
Leaf Area Index \\
(LAI), Nitrogen, \\
Plant densities, \\
PAR, RUE, Rice. \\
\hline Article Info \\
\hline $\begin{array}{l}\text { Accepted: } \\
17 \text { April } 2017 \\
\text { Available Online: } \\
\text { 10 May } 2017\end{array}$ \\
\hline
\end{tabular}

A field experiment was conducted at Agricultural Research Institute, Rajendranagar, Hyderabad during the Kharif season of 2012 with four nitrogen levels $\left(120 \mathrm{~kg} \mathrm{ha}^{-1}, 180 \mathrm{~kg}\right.$ $\mathrm{ha}^{-1}, 240 \mathrm{~kg} \mathrm{ha}^{-1}$ and $\left.300 \mathrm{~kg} \mathrm{ha}^{-1}\right)$ as factor one and three plant densities - farmers practice zigzag planting $\left(28\right.$ hills m $\left.\mathrm{m}^{-2}\right), 15 \times 15 \mathrm{~cm}\left(44.44\right.$ hills m$\left.^{-2}\right), 25 \times 25 \mathrm{~cm}\left(16\right.$ hills m$\left.^{-2}\right)$ as factor two in randomized block design with factorial concept replicated thrice. Increased number of tillers $\mathrm{m}^{-2}$, leaf area index (LAI), intercepted radiation and radiation use efficiency (RUE) was noticed with increased plant density from 16 to 44.44 hills $\mathrm{m}^{-2}$. Application of $300 \mathrm{~kg} \mathrm{~N} \mathrm{ha}^{-1}$ showed more number of tillers $\mathrm{m}^{-2}$, LAI, intercepted radiation and RUE and was onpar with $180 \mathrm{~kg} \mathrm{~N}^{-1}$. A highly significant linear relationship observed between cumulative intercepted photosynthetically active radiation (PAR) and biomass production. So plant density of 44.44 hills $\mathrm{m}^{-2}$ and application of $180 \mathrm{~kg} \mathrm{~N} \mathrm{ha}^{-1}$ could be considered as optimum for improved growth and radiation use efficiency of transplanted rice in South Telangana Region of Telangana State.

\section{Introduction}

Rice (Oryza sativa L.) is the world's second most important cereal crop and staple food for more than $60 \%$ of the global population. It is estimated that more than $50 \mathrm{~kg}$ of rice being consumed per capita per year worldwide (FAO, 2016). Since the world population is increasing at $1.17 \%$ annually, an annual increase in rice production by $0.6-0.9 \%$ is required until 2050 to meet the anticipated demand (Carriger and Vallee, 2007). India ought to add 1.7 million tones of additional rice every year to ensure national food security (Dass and Chandra, 2013). Previously, this demand was met by extending the area under cultivation, aided by advancement in irrigation facilities. In future, the competition for land and other natural resources will render it difficult to extend the area. This puts a huge challenge to the rice scientists as the incremental rice productions are to be met from shrinking, depleting resources and changing climate situations. Hence, to sustain the rice yields with improved resource use efficiency, attempts should be made to increase the yield per unit area through improved technology and proper agronomic management practices. Among the crop management practices, judicious application of nitrogenous fertilizer with optimum plant density is paramount important for yield enhancement and improved resource use in rice. 
Nitrogen is the kingpin for any fertilizer management programme in rice cultivation. Inadequate $\mathrm{N}$ leads to reduced leaf area, thereby, limiting light interception, photosynthesis and finally biomass growth, grain yield, radiation use efficiency and water productivity (Sinclair, 1999). Therefore, using higher $\mathrm{N}$ rates for increasing rice yield is a promising management recommendation. When $\mathrm{N}$-fertilizer is applied in proper amount at correct time, $\mathrm{N}$-fertilizer recovery can be achieved up to $50-70 \%$ of total nitrogen applied (Wang et al., 2002 and Ligeng et al., 2004).

Plant density plays a key role in boosting rice yields, as it influences the tiller formation, solar radiation interception, nutrient uptake, rate of photosynthesis and ultimately affect the growth and development of rice plant. The amount of solar radiation intercepted by a crop is a major determinant of the total dry matter (TDM) produced (Biscoe and Gallagher, 1978). Optimum plant spacing ensures plants to grow properly both in their aerial and underground parts through utilization of solar radiation and nutrients, therefore proper manipulation of planting density may lead to increase in the economic yield of transplanted rice. Considering these facts, the present study was undertaken to determine the suitable plant density and nitrogen level for optimum growth and improved radiation use efficiency of transplanted rice.

\section{Materials and Methods}

The experiment was conducted at Agricultural Research Institute, Professor Jayashankar Telangana State Agricultural University, Rajendranagar, Hyderabad during the period from July to November 2012. The soil of the experimental site was sandy loam in texture, alkaline in reaction, low in available nitrogen, phosphorus and high in available potassium. The experiment was laid out in a factorial randomized complete block design with three replications. The treatments comprised of three plant densities $\left(\mathrm{PD}_{1}\right.$ - farmers practice: 28 hills $\mathrm{m}^{-2}, \mathrm{PD}_{2}-15 \times 15 \mathrm{~cm}: 44.44$ hills $\mathrm{m}^{-2}$ and $\mathrm{PD}_{3}-25 \times 25 \mathrm{~cm}: 16$ hills $\mathrm{m}^{-2}$ ) and four nitrogen levels $\left(\mathrm{N}_{1}: 120, \mathrm{~N}_{2}: 180, \mathrm{~N}_{3}: 240\right.$ and $\mathrm{N}_{4}$ : $300 \mathrm{~kg} \mathrm{ha}^{-1}$ ). Cultivar MTU 1010 was used as test variety. Recommended dose of $\mathrm{P}_{2} \mathrm{O}_{5}, \mathrm{k}_{2} \mathrm{O}$ and $\mathrm{Zn}$ fertilizers were applied @ 60,40 and $50 \mathrm{~kg} \mathrm{ha}^{-1}$ through single super phosphate (SSP), muriate of potash (MOP) and zinc sulphate. The whole amount of SSP, MoP and $\mathrm{ZnSO}_{4}$ were applied at the time of final land preparation. Nitrogen was applied as per the treatments in the form of urea (46\% $\mathrm{N}$ ) in three equal splits at planting, 20 days after planting (DAP) and at panicle initiation (PI) stage. Irrigation along with other intercultural operations was done as and when required. Data on plant height, tiller number and leaf area index were collected as per standard procedures.

\section{Radiation interception and radiation use efficiency}

Canopy light interception was measured between 11.00 and $13.00 \mathrm{~h}$ at mid tillering, panicle initiation, Heading and physiological maturity stages using Sunscan Canopy Analysis System. In each plot, incident, transmitted and reflected photosynthetically active radiation (PAR) were measured periodically at the top, middle and bottom of rice crop throughout the season. These measurements were used to derive the Intercepted PAR (IPAR). Intercepted radiation during the entire growing season was the summation of intercepted radiation during each growth period. Radiation use efficiency (RUE) was calculated as the ratio of above ground total dry weight to intercepted radiation during the entire growing season. The collected data were statistically analyzed and mean differences were compared using SAS programme. 


\section{Results and Discussion}

\section{Plant height (cm)}

Plant height increased progressively with advancement of crop growth and attaining maximum at physiological maturity stage. The rate of increase, however, varied depending on the growth stages. A significant variation in plant height was observed due to nitrogen levels at heading, dough and physiological maturity stages but not with planting density (Table 1). Even though 300 $\mathrm{kg} \mathrm{N}$ ha $^{-1}$ recorded significantly more plant height and was comparable with 240 and 180 $\mathrm{kg} \mathrm{N} \mathrm{ha}{ }^{-1}$. These were significantly superior to $120 \mathrm{~kg} \mathrm{~N} \mathrm{ha}^{-1}$ application. The increase in plant height with increased nitrogen application irrespective of plant density might be primarily due to enhanced vegetative growth with more nitrogen supply to plant. Sharma et al., (2012) also reported taller plants at higher (150 and $180 \mathrm{~kg} \mathrm{ha}^{-1}$ ) levels of nitrogen application than at lower level of $\mathrm{N}\left(120 \mathrm{~kg} \mathrm{ha}^{-1}\right)$.

\section{Number of tillers $\mathbf{m}^{-2}$}

The tiller production initiated at 17 days after transplanting (DAT) and thereafter it was increased linearly as the crop growth progressed and reached to maximum at 31-38 days after transplanting (maximum tillering stage), but thereafter it decreased gradually towards maturity stage due to tiller mortality and the senescence of plants (Figs. 1\&2). These results were in conformity with findings of Yoshida (1981) where the tiller number declines after the maximum tillering stage. Significant increase in tillers $\mathrm{m}^{-2}$ was observed with increase in plant density from 16 to 44.44 hills $\mathrm{m}^{-2}$ and the highest number of tillers $\mathrm{m}^{-2}$ was recorded with 44.44 hills $\mathrm{m}^{-2}$ at all the crop growth stages and was significantly superior to 28 and 16 hills $\mathrm{m}^{-2}$, which in turn recorded the lowest number of tiller $\mathrm{m}^{-2}$. This more number of tillers $\mathrm{m}^{-2}$ at higher plant densities might be due to more plants $\mathrm{m}^{-2}$ (Yadav, 2007). There was a significant effect of graded levels of nitrogen on tillers $\mathrm{m}^{-2}$. More tillers $\mathrm{m}^{-2}$ was observed with $180 \mathrm{~kg} \mathrm{~N} \mathrm{ha}^{-1}$ and was on a par with 240 $\mathrm{kg} \mathrm{N} \mathrm{ha}^{-1}$ and $300 \mathrm{~kg} \mathrm{~N} \mathrm{ha}^{-1}$ and significantly superior to $120 \mathrm{~kg} \mathrm{~N}^{-1}$. The increase in tillers $\mathrm{m}^{-2}$ might be due to increased cell division and cell expansion with the increased $\mathrm{N}$ availability (Sharma et al., 2012).

\section{Leaf area index}

LAI of rice with varied planting density and nitrogen levels showed substantial differences over the growth stages (Table 2). LAI values increased sharply, reached maximum at heading stage and then decreased irrespective of treatment differences. The rate of decrease of LAI after attaining peak was more rapid. Significantly higher leaf area index values was noticed at tillering and heading stages with 44.44 hills $\mathrm{m}^{-2}$, and was on par with 28 hills $\mathrm{m}^{-2}$, and were significantly superior to 16 hills $\mathrm{m}^{-2}$. The higher LAI at increased plant density might be due to more number of leaves produced per unit area (Yadav, 2007). With respect to nitrogen levels, maximum LAI was obtained from $300 \mathrm{~kg} \mathrm{~N} \mathrm{ha}^{-1}$ and it was on par with 240 and $180 \mathrm{~kg} \mathrm{~N} \mathrm{ha}^{-1}$ and were significantly superior to $120 \mathrm{~kg} \mathrm{~N} \mathrm{ha}^{-1}$. The increased LAI was due to more number of leaves and their better growth under adequate nitrogen (Sharma et al., 2012).

\section{Intercepted radiation}

Plant density and $\mathrm{N}$ levels differed substantially in intercepted radiation. Light intercepted values varied from 38 to $54 \%$ at tillering and steadily increased, reached maximum at heading stage and thereafter, $\%$ interception decreased as the crop proceeds towards physiological maturity. This was due to senescence of leaves and tiller mortality. 
Per cent light interception increased with increasing planting density from 16 to 44.4 hills $\mathrm{m}^{-2}$ and the highest per cent interception was recorded with 44.4 hills $\mathrm{m}^{-2}$ at all the stages of crop growth. This might be due to increased leaf area index at higher plant densities over low plant densities. Development of adequate leaf area index necessary for interception and utilization of incident solar radiation is important and has been shown to be closely related to final grain yield (Baloch et al., 2006). The present results are in agreement with the recent findings of Gorgy et al., (2010), where increased plant density (33 hills $\mathrm{m}^{-2}$ ) reduced the light intensity between rows of transplanted rice with increased light interception. Among the nitrogen levels, higher \% light interception was observed with $300 \mathrm{~kg}$ followed by 240 ,
180 and $120 \mathrm{~kg} \mathrm{~N} \mathrm{ha}^{-1}$. At higher nitrogen levels, higher light interception might be due to more tillers $\mathrm{m}^{-2}$, leaf area index, dry matter production. Similar results were reported by Haque et al., (2006) where significantly higher light interception was observed at heading stage with increasing nitrogen levels (Table 3).

\section{Radiation use efficiency (RUE)}

Radiation use efficiency is increased as the crop age progressed and it was varied with plant densities and nitrogen levels. Higher RUE was observed with 44.44 hills $\mathrm{m}^{-2}$ and was followed by 28 hills $\mathrm{m}^{-2}$ and the lowest values were observed with 16 hills $\mathrm{m}^{-2}$ (Table 4).

Table.1 Effect of plant densities and nitrogen levels on plant height of rice

\begin{tabular}{|c|c|c|c|c|c|}
\hline \multirow{2}{*}{ Treatments } & \multicolumn{5}{|c|}{ Plant height $(\mathrm{cm})$} \\
\hline & Tillering & PI & Heading & Dough & PM \\
\hline \multicolumn{6}{|c|}{ Plant densities (PD) $\left(\right.$ hills $\left.\mathrm{m}^{-2}\right)$} \\
\hline Farmers practice ( 28$)$ & 33 & 68 & 93 & 110 & 111 \\
\hline $15 \times 15 \mathrm{~cm} \quad(44.44)$ & 33 & 68 & 93 & 110 & 110 \\
\hline $25 \times 25 \mathrm{~cm}(16)$ & 34 & 68 & 92 & 112 & 112 \\
\hline SEd \pm & 0.7 & 0.5 & 1.3 & 1.3 & 1.3 \\
\hline $\mathrm{CD}(\mathrm{P}=0.05)$ & NS & NS & NS & NS & NS \\
\hline \multicolumn{6}{|l|}{ Nitrogen $(\mathrm{N})\left(\mathrm{kg} \mathrm{ha}^{-1}\right)$} \\
\hline 120 & 33 & 68 & $89^{b}$ & $105^{b}$ & $106^{b}$ \\
\hline 180 & 33 & 68 & $93^{\mathrm{a}}$ & $111^{\mathrm{a}}$ & $111^{\mathrm{a}}$ \\
\hline 240 & 34 & 68 & $94^{\mathrm{a}}$ & $112^{\mathrm{a}}$ & $113^{\mathrm{a}}$ \\
\hline 300 & 34 & 69 & $94^{\mathrm{a}}$ & $114^{\mathrm{a}}$ & $114^{\mathrm{a}}$ \\
\hline SEd \pm & 0.8 & 0.6 & 1.1 & 1.5 & 1.5 \\
\hline $\mathrm{CD}(\mathrm{P}=0.05)$ & NS & $\mathrm{NS}$ & 3.1 & 3.2 & 3.0 \\
\hline \multicolumn{6}{|l|}{ Interaction $(\mathrm{PD} \times \mathrm{N})$} \\
\hline SEd \pm & 1.4 & 1.0 & 2.6 & 2.6 & 2.5 \\
\hline $\mathrm{CD}(\mathrm{P}=0.05)$ & NS & $\mathrm{NS}$ & NS & NS & NS \\
\hline
\end{tabular}

Note: Means with same letter are not significantly different. PI- panicle initiation; PM- physiological maturity 
Table. 2 Leaf area index (LAI) of rice at different growth stages as influenced by plant densities and nitrogen levels

\begin{tabular}{|c|c|c|c|c|}
\hline \multirow[t]{2}{*}{ Treatments } & \multicolumn{4}{|c|}{ Leaf area index } \\
\hline & Tillering & PI & Heading & PM \\
\hline \multicolumn{5}{|c|}{ Plant densities (PD) (hills $\mathrm{m}^{-2}$ ) } \\
\hline Farmers practice (28) & $0.78^{\mathrm{b}}$ & 2.21 & $4.26^{\mathrm{ab}}$ & 2.40 \\
\hline $15 \times 15 \mathrm{~cm} \quad(44.44)$ & $1.06^{\mathrm{a}}$ & 2.30 & $4.37^{\mathrm{a}}$ & 2.50 \\
\hline $25 \times 25 \mathrm{~cm}(16)$ & $0.52^{\mathrm{c}}$ & 1.88 & $3.92^{\mathrm{b}}$ & 2.27 \\
\hline SEd + & 0.1 & 0.2 & 0.1 & 0.2 \\
\hline $\mathrm{CD}(\mathrm{P}=0.05)$ & 0.2 & NS & 0.3 & NS \\
\hline \multicolumn{5}{|l|}{ Nitrogen $(\mathrm{N})\left(\mathrm{kg} \mathrm{ha}^{-1}\right)$} \\
\hline 120 & $0.58^{\mathrm{b}}$ & $1.56^{\mathrm{b}}$ & $3.16^{\mathrm{b}}$ & $1.53^{\mathrm{b}}$ \\
\hline 180 & $0.84^{\mathrm{a}}$ & $2.22^{\mathrm{a}}$ & $4.40^{\mathrm{a}}$ & $2.55^{\mathrm{a}}$ \\
\hline 240 & $0.88^{\mathrm{a}}$ & $2.31^{\mathrm{a}}$ & $4.54^{\mathrm{a}}$ & $2.64^{\mathrm{a}}$ \\
\hline 300 & $0.83^{\mathrm{a}}$ & $2.41^{\mathrm{a}}$ & $4.63^{\mathrm{a}}$ & $2.83^{\mathrm{a}}$ \\
\hline $\mathrm{SEd} \pm$ & 0.1 & 0.2 & 0.2 & 0.2 \\
\hline $\mathrm{CD}(\mathrm{P}=0.05)$ & 0.2 & 0.5 & 0.3 & 0.4 \\
\hline \multicolumn{5}{|l|}{ Interaction $(\mathrm{PD} \times \mathrm{N})$} \\
\hline SEd \pm & 0.2 & 0.4 & 0.3 & 0.4 \\
\hline $\mathrm{CD}(\mathrm{P}=0.05)$ & NS & NS & NS & NS \\
\hline
\end{tabular}

Note: Means with same letter are not significantly different.

PI- panicle initiation; PM- physiological maturity.

Table.3 Intercepted PAR (\%) of rice at different growth stages as influenced by plant densities and nitrogen levels

\begin{tabular}{|c|c|c|c|c|}
\hline Treatments & Tillering & $\begin{array}{c}\text { Panicle } \\
\text { initiation }\end{array}$ & Heading & $\begin{array}{c}\text { Physiological } \\
\text { maturity }\end{array}$ \\
\hline \multicolumn{5}{|c|}{ Plant densities (PD) $\left(\right.$ hills $\left.\mathrm{m}^{-2}\right)$} \\
\hline Farmers practice ( 28$)$ & 45.02 & 65.63 & 89.92 & 88.19 \\
\hline $15 \times 15 \mathrm{~cm} \quad(44.44)$ & 53.56 & 69.22 & 92.95 & 88.96 \\
\hline $25 \times 25 \mathrm{~cm} \mathrm{(16)}$ & 37.88 & 59.02 & 89.76 & 86.36 \\
\hline \multicolumn{5}{|l|}{ Nitrogen $(\mathrm{N})\left(\mathrm{kg} \mathrm{ha}^{-1}\right)$} \\
\hline 120 & 36.40 & 56.25 & 86.39 & 80.64 \\
\hline 180 & 47.36 & 62.63 & 90.30 & 87.26 \\
\hline 240 & 48.07 & 68.11 & 93.05 & 90.47 \\
\hline 300 & 50.12 & 71.52 & 93.78 & 92.97 \\
\hline
\end{tabular}


Table.4 Radiation use efficiency $\left(\mathrm{g} \mathrm{MJ}^{-1}\right)$ of rice at different growth stages as influenced by plant densities and nitrogen levels

\begin{tabular}{|l|c|c|c|c|}
\hline Treatments & Tillering & $\begin{array}{c}\text { Panicle } \\
\text { initiation }\end{array}$ & Heading & $\begin{array}{c}\text { Physiological } \\
\text { maturity }\end{array}$ \\
\hline Plant densities (PD) (hills m & \\
\hline Farmers practice $(28)$ & 141 & 615 & 1263 & 1831 \\
\hline $15 \times 15 \mathrm{~cm} \mathrm{(44.44)}$ & 169 & 637 & 1227 & 1796 \\
\hline $25 \times 25 \mathrm{~cm}(16)$ & 108 & 543 & 1123 & 1717 \\
\hline Nitrogen (N) $\left(\mathrm{kg} \mathrm{ha}^{-1}\right)$ & 118 & 524 & 1090 & 1607 \\
\hline 120 & 146 & 597 & 1211 & 1781 \\
\hline 180 & 150 & 666 & 1223 & 1828 \\
\hline 240 & 144 & 608 & 1293 & 1909 \\
\hline 300 & \multicolumn{5}{|l}{} \\
\hline
\end{tabular}

Fig.1 Progress of tiller production (tillers $\mathrm{m}^{-2}$ ) of rice under different nitrogen levels

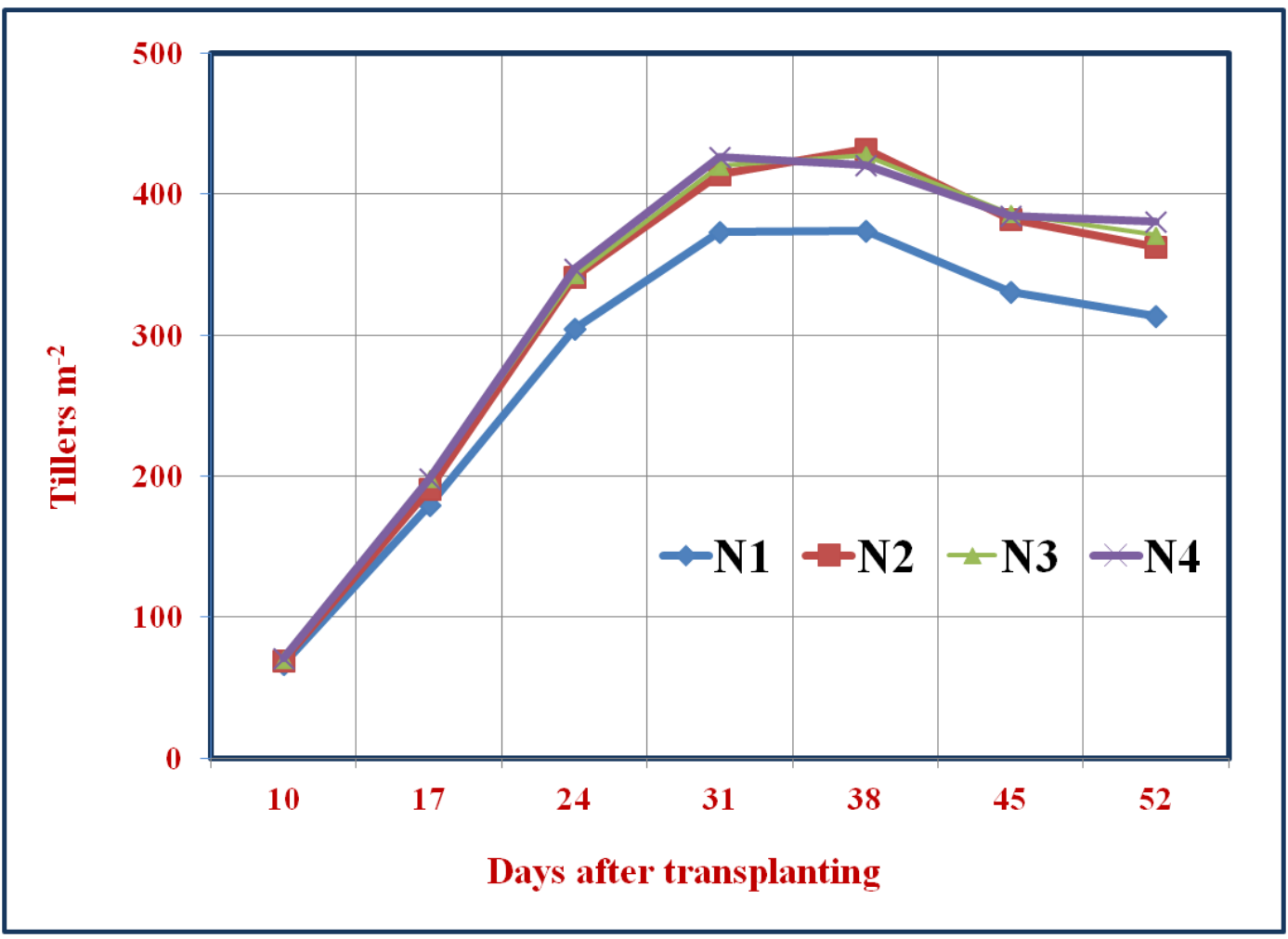


Fig.2 Progress of tiller production (tillers $\mathrm{m}^{-2}$ ) of rice under different plant densities

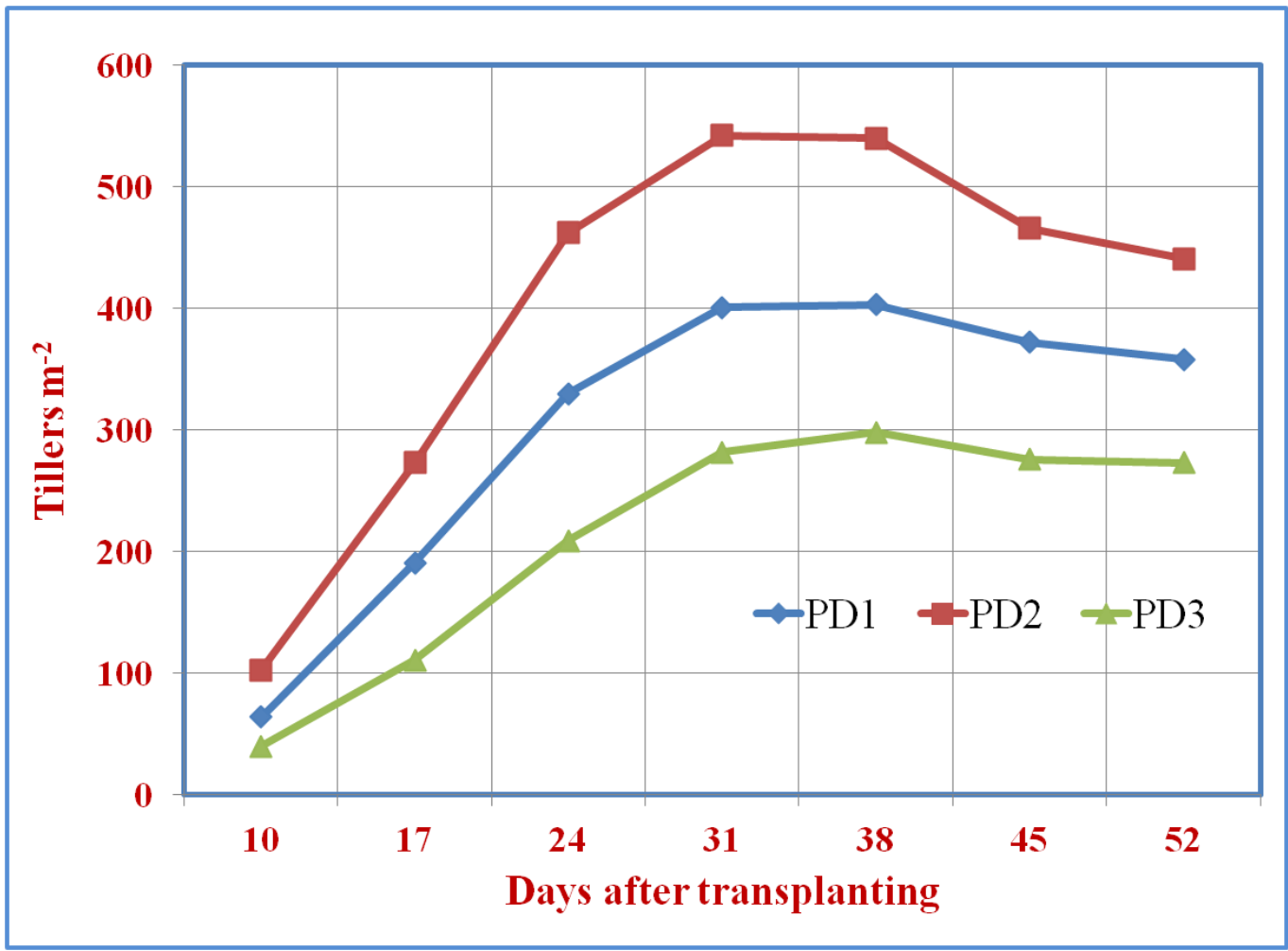

Fig.3 Relationship between intercepted PAR and biomass of rice under variable plant densities and nitrogen levels

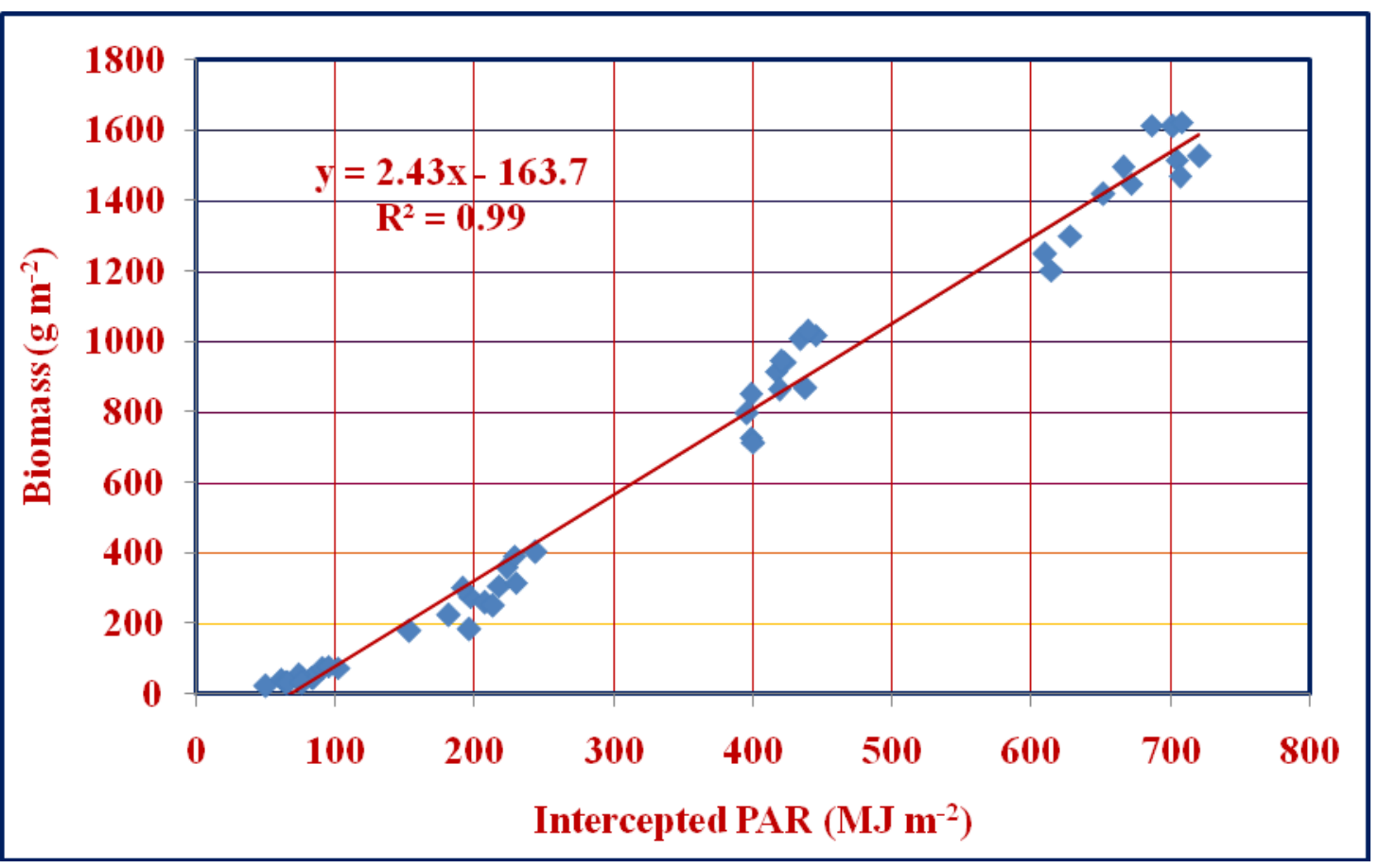


Considering the nitrogen application, as the $\mathrm{N}$ rate increased RUE increased. Highest RUE was noticed with $300 \mathrm{~kg} \mathrm{~N}^{-1}$ and the values decreased with corresponding decrease in nitrogen rate, with lowest values in $120 \mathrm{~kg} \mathrm{~N}$ $\mathrm{ha}^{-1}$. Increased RUE with increasing nitrogen fertilizer dose has been reported in several experiments (Biouki et al., 2014). The difference in RUE could be due to difference in the absorbed PAR (Siddique et al., 1989). Further environment, management and plant factors such as nitrogen status of the plant also alter the RUE (Board, 2000).

There was a strong and linear relationship between total biomass and intercepted PAR (Fig. 3). The common regression revealed that intercepted PAR accounted for $99 \%$ variability in the biomass, and the regression gave a value of $2.43 \mathrm{~g} \mathrm{MJ}^{-1}$. Thus, overall RUE of rice for South Telangana Zone of Telangana State was estimated to be $2.43 \mathrm{~g}$ $\mathrm{MJ}^{-1}$. Similar results were reported by Ahmad et al., (2008) who stated that total dry matter and accumulated intercepted PAR were linearly related. Kiniry et al., (1989) reported RUE of $2.2 \mathrm{~g} \mathrm{MJ}^{-1}$ of intercepted PAR for a non-stressed rice crop.

In conclusion, plant density of 44.44 hills $\mathrm{m}^{-2}$ along with application of $180 \mathrm{~kg} \mathrm{~N} \mathrm{ha}^{-1}$ should be considered optimum for improving growth performance and radiation use efficiency of transplanted rice in South Telangana region of Telangana State.

\section{References}

Ahmad, S., M. Zia-ul-Ha, H. Ali, S.A. Shad, A. Ahmad, M. Maqsood, M.B. Khan, S. Mehmood and Hussain, A. 2008. Water and radiation use efficiencies of transplanted rice (Oryza sativa L.) at different plant densities and irrigation regimes under semi-arid environment. Pak. J. Bot., 40(1): 199-209.
Baloch, M.S., I.U. Awan and Hassan, G. 2006. Growth and yield of rice as affected by transplanting dates and seedlings per hill under high temperature of Dera Ismail Khan, Pakistan. J. Zhejiang Univ. Sci. A., 7: 572-577.

Biscoe, P.V., and Gallagher, J.N. 1978. Physical analysis of cereal yield. I. Production of dry matter. Agric. Progress, 34-50.

Board, J. 2000. Light interception efficiency and light quality affect yield compensation of soybean at low plant population. Crop Sci., 40: 1285-1294.

Carriger, S., and Vallee, D. 2007. More crop per drop, Rice today.

Dass, A., and Chandra, S. 2013. Irrigation, spaqcing and cultivar effects on net photosynthetic rate, dry matter partitioning and productivity of rice under system of rice intensification in Mollisol of Northern India. Exp Agric., 49(4): 504-23

FAO. 2016. FAOSTAT Data (available at: http://faostat3. fao.org/browse/FB/CC/E [Accessed on 03 March 2016]).

Gorgy, R.N. 2010. Effect of transplanting spacings and nitrogen levels on growth, yield and nitrogen use efficiency of some promising rice varieties. J Agric Res., Kafer El-Shiekh University. 36(2): 2010.

Haque, K.M.S., Q.A. Khaliq and Aktar, J. 2006. Effect of nitrogen on phenology, light interception and growth in aromatic rice. 2006. Int. J. Sust. Crop Prod., 1(2): 01-06.

Kiniry, J.R., C.A. Jones, J.C. O'Toole, R. Blanchet, M. Cabelguenne and Spanel, D.A. 1989. Radiation-use-efficiency in biomass accumulation prior to grain filling for five grain crop species. Field Crops Res., 20: 51-64.

Ligeng, J., D. Tingbo, J. Dong, C. Weixing, G. Xiuqin and Shanqing, W. 2004. 
Characterizing physiological N-use efficiency as influenced by nitrogen management in three rice cultivars. Field Crops Res., 83: 239.

Sharma, P., V. Abrol and Kumar, R. 2012. Effect of water regimes and nitrogen levels on rice crop performance and nitrogen uptake. Ind. J. Soil Conserv., 40(2): 122-128.

Siddique, K.H.M., R.K. Belford, M.W. Perry and Tennant, D. 1989. Growth, development and light interception of old and modern wheat cultivars in a Mediterranean type environment. Aust. J. Agric. Res., 40: 473-487

Sinclair, T.R., and Muchow, R.C. 1999. Radiation use efficiency, In: $A d v$ Agron., 215-265.

Wang, H., B. A. M. Bouman, Z. Dule, C, Wang and Moya, P.F. 2002. Aerobic rice in northern China: opportunities and challenges. In Bouman, B. A. M., Hengsdijk, H., Hardy, B., Bindraban, P. S., Tuong, T. P., Ladha, J. K. (Eds.), Water-Wise Rice Production. Proceedings of the International Workshop on Water Wise Rice Production, 8-11 April. International Rice Research Institute (pp. 143- 154), Los Banos, Philippines.

Yadav, V.K. 2007. Studies on the effect of dates of planting, plant geometry and number of seedlings per hill in hybrid rice (Oryza sativa 1.). Ph D Thesis. Chandra Shekhar Azad University of Agriculture and Technology, Kanpur208002 (U.P.) India.

Yoshida, S. 1981. Fundamentals of rice crop science. International Rice Research Institute, Los Banos, Phillipines. 269.

\section{How to cite this article:}

Swarna, R., P. Leela Rani, G. Sreenivas, D. Raji Reddy and Madhavi, A. 2017. Growth Performance and Radiation Use Efficiency of Transplanted Rice under Varied Plant Densities and Nitrogen Levels. Int.J.Curr.Microbiol.App.Sci. 6(5): 1429-1437.

doi: https://doi.org/10.20546/ijcmas.2017.605.156 